Original Research Paper

\title{
Upaya Meningkatkan Kemampuan Analisis Siswa Melalui Model Pembelajaran Berbasis Masalah Pada Materi Kelistrikan Mesin
}

\author{
Anwar Muhaimin ${ }^{1}$ \\ ${ }^{1}$ Sekolah Menengah Kejuruan Negeri 3 Mataram, Indonesia.
}

*Corresponding Author: Anwar Muhaimin, Sekolah Menengah Kejuruan Negeri 3 Mataram, Indonesia; Email: anwarmuhaimin@yahoo.com

\begin{abstract}
Abstrak: Penelitian ini bertujuan untuk mengetahui pengaruh penerapan model pembelajaran berbasis masalah terhadap peningkatan kemampuan analisis siswa kelas X Teknik Pemesinan SMK Negeri 3 Mataram pada mata pelajaran Kelistrikan Mesin. Penelitian ini merupakan penelitian tindakan kelas dengan menerapkan dua siklus. Pengukuran kemampuan analisis berdasarkan indikator kemampuan analisis differentiatin, organizing, dan attributing. Hasil penelitian menunjukkan pada siklus I, siswa yang mencapai nilai ketuntasan belajar pada ketiga indikator tersebut kurang dari $80 \%$.Pada siklus II terdapat $80 \%$ siswa yang mencapai nilai ketuntasan belajar pada indikator differentiating, $80 \%$ pada indikator organizing, dan $82.5 \%$ pada indikator attributing. Peningkatan kemampuan analisis siswa dihitung menggunakan $\mathrm{N}$-gain. Berdasarkan nilai $\mathrm{N}$-gain di siklus I diperoleh peningkatan kemampuan analisis kategori sedang pada setiap indikator, sedangkan di siklus II diperoleh peningkatan kemampuan analisis kategori sedang pada indikator differentiating, dan kategori tinggi pada indikator organizingdan attributing. Pengujian statistik terhadap $\mathrm{N}$-gain dengan uji-t menunjukkan bahwa pembelajaran berbasis masalah berpengaruh terdapat peningkatan kemampuan analisis siswa secara signifikan.
\end{abstract}

Kata Kunci: Kemampuan Analisis Siswa, Pembelajaran Berbasis Masalah

\section{Pendahuluan}

Salah satu materi pembelajaran yang disampaikan untuk Sekolah Menengah Kejuruan (SMK) paket keahlian Teknik Pemesinan adalah mata pelajaran Kelistrikan Mesin dan Konversi Energi yang masuk pada kelompok mata pelajaran Dasar Program Keahlian yang disampaikan pada kelas X (Kemendiknas, 2013). Kompetensi dasar yang menjadi muatan materi ini antara lain: (1) prinsip-prinsip dasar kelistrikan; (2) rangkaian kelistrikan sederhana, (3) komponen-komponen listrik dan elektronik; dan (4) mesin listrik (Kemendiknas, 2013). Tuntutan kompetensi inti pada ranah pengetahuan dari mata pelajaran ini adalah sampai pada tingkatan menganalisis (C4) dari berbagai bentuk pengetahuan dalam rangka memecahkan permasalahan yang diberikan.

Mata pelajaran Kelistrikan Mesin dan Konversi Energi sesuai dengan Struktur Kurikulum yang berlaku disampaikan dalam dua semester. Model pembelajaran yang diterapkan oleh peneliti dalam penyampaian materi ini sebelumnya adalah model pembelajaran inkuiri terbimbing. Dalam rangka mendukung pelaksanaan model ini, peneliti melakukan inovasi dengan mengembangkan media pembelajaran kelistrikan mesin dalam bentuk media riil. Melalui tahap pengujian, pembelajaran kelistrikan mesin yang disampaikan menggunakan media yang dikembangkan memberikan pengaruh yang lebih baik terhadap pemahaman konsep siswa dibandingkan dengan pembelajaran konvensional (Muhaimin, 2015). Pencapaian hasil belajar siswa sesuai kriteria ketuntasan belajar sampai pada tingkat memahami (C2) telah dipenuhi oleh sebagian besar siswa. Ketika siswa dihadapkan pada permasalahan-permasalahan kelistrikan mesin dengan tingkat $\mathrm{C} 2,87 \%$ dari keseluruhan jumlah siswatelah mencapai nilai diatas nilai ketuntasan belajar yang ditetapkan. Permasalahan yang timbul adalah ketika siswa disajikan pemecahan masalah 
yang menuntut kemampuan analisis, ternyata hanya $32 \%$ siswa yang mampu memenuhi nilai ketuntasan belajar. Permasalahan ini merupakan kesenjangan antara kondisi nyata dengan kondisi ideal yang diharapkan. Oleh karena itu, perlu diupayakan penerapan model pembelajaran yang tepat dalam rangka meningkatkan kemampuan siswa agar dalam menyelesaikan permasalahan yang ada melalui kemampuan analisis.

Salah satu aspek kognitif dalam Taksnomi Bloom adalah aspek analisis. Kemampuan analisis dapat dicapai oleh siswa berdasarkan pada kemampuan-kemampuan yang diperoleh sebelumnya. Mengutip Teori Bloom, DitPSMK (2017) menyatakan bahwa kemampuan berpikir analisis merupakan kemampuan dalam mengurai permasalahan menjadi bagian-bagian yang lebih khusus atau lebih kecil selanjutnya bagian-bagian tersebut diorganisir untuk diketahui keterkaitan hubungannya. Anderson \& Krathwohl (2010) mendefinisikan kemampuan analisis sebagai kemampuan untuk mengurai atau memisahkan suatu hal kedalam bagian-bagiannya dan dapat mencari keterkaitan antar bagian-bagian tersebut. Marzano \& Kendall (2008) mendefinisikan kemampuan analisis sebagai kemampuan untuk merinci suatu permasalahan mejadi komponen-komponen yang penting dan tidak penting serta mampu membandingkan komponen-komponen tersebut dan mencari hubungan-hubungannya. Berdasarkan dari beberapa definisi tersebut dapat disimpulkan bahwa kemampuan analisis merupakan kemampuan berpikir siswa dalam menjabarkan suatu permasalahan menjadi pengetahuan-pengetahuan yang lebih spesifik yang merupakan perpanjangan dari pengetahuan sebelumnya, selanjutnya mengorganisir pengetahuan-pengetahuan tersebut untuk dibandingkan dan dicari bentuk hubungannya dalam rangka memecahkan suatu permasalahan.

Kemampuan analisis merupakan kemampuan yang menunjukkan cara berpikir siswa yang dapat diukur. Indikator-indikator kemampuan analisis merupakan dasar dari pengembangan instrumen guna mengukur tingkat kemampuan analisis siswa.. Anderson \& Krathwohl (2010 menyebutkan bahwa kemampuan analisis siswa dapat diukur melalui kegiatan: (1) differentiating, yaitu mengukur kemampuan siswa dalam membedakan bagianbagian dari sebuah struktur pengetahuan dari sebuah permasalahan yang penting dan saling berkaitan; (2) organizing, kemampuan siswa dalam menandai bagian-bagian penyusun sebuah pengetahuan dan menyusun bagian-bagian tersebut menjadi struktur pengetahuan yang relevan sebagai pemecahan masalah; dan (3) attributing, kemampuan siswa dalam menghubungkan pokok-pokok permasalahan, kata kunci-kata kunci, sudut pandang-sudut pandang, atau perhatian-perhatian utama dari sebuah permasalahan. Sedangkan Marzano \& Kendall (2008) menyatakan bahwa proses analisis meliputi: (1) matching, yaitu kemampuan siswa dalam menentukan hal-hal yang mirip dan yang berbeda dari baian-bagian penyusun pengetahuan; (2) classifying, kemampuan siswa dalam mengelomokkan pengetahuan menjadi sesuatu yang bermakna, (3) analyzing error, kemampuan siswa dalam memberikan alasan yang tepat dari sebuah pengetahuan; dan (4) generalizing, kemampuan siswa menyusun kesimpulan baru berdasarkan pengetahuan yang diperoleh sebelumnya.

Pembelajaran Berbasis Masalah merupakan salah satu model pembelajaran inovatif yang dapat memfasilitasi siswa untuk aktif. Secara garis besar, pembelajaran berbasis masalah terdari dari kegiatan menyajikan kepada siswa situasi masalah yang otentik dan bermakna yang dapat memberikan kemudahan kepada siswa dalam melakukan penyelidikan guna mengkonstruksi pengetahuannya. Trilling \& Fadel (2009) mendefiniskan pembelajaran berbasis masalah sebagai pembelajaran yang menggunakan berbagai kemampuan berpikir dari peserta didik secara individu maupun kelompok serta lingkungan nyata (autentik) untuk mengatasi permasalahan sehingga bermakna, relevan, dan kontekstual. Penerapan pembelajaran berbasis masalah sebagai pembelajaran untuk pemecahan masalah yang komplek, problem-problem nyata dengan menggunakan pendekataan studi kasus. Peserta didik melakukan penelitian dan menetapan solusi untuk pemecahan masalah. Ibrahim \& Nur (2000) menjelaskan bahwa pembelajaran berbasis masalah merupakan pembelajaran yang memiliki karakteristik adanya pertanyaan atau masalah otentik yang diperlukan berbagai macam solusi, memerlukan kegiatan siswa untuk melakukan penyelidikan, dan membutuhkan kerja sama antar siswa. Berdasarkan pada definisi-definsi tersebut dapat disimpulkan bahwa pembelajaran berbasis masalah merupakan model pembelajaran berpusat pada siswayang memfasilitasi siswa untuk belajar melalui keterlibatan dalam masalah nyata, dimana 
siswa dapat mengkonstruksi pemahamannya sendiri melalui kegiatan menyusun permasalahan, mendiskusikan pemecahan masalah, menyajikan solusi, dan membuat reflesi. DitPSMK (2017) menjabarkan sintaks pembelajaran berbasis masalah, yaitu: (1) orientasi siswa pada masalah; (2) mengorganisasi siswa untuk belajar; (3) membimbing penyelidikan individu maupun kelompok; (4) mengembangkan dan menyajikan hasil karya; dan (5) menganalisis dan mengevaluasi proses pemecahan masalah.

Orientasi siswa pada masalah dalam sintaks pembelajaran berbasis masalah merupakan kegiatan dimana guru menjelaskan tujuan pembelajaran serta memotivasi siswa agar terliat dalam pemecahan masalah (Hartono, 2014). Sedangkan kegiatan mengorganisasi siswa pada belajar intinya adalah bantaun yang diberikan guru kepada siswa dalam mengorganisasi tugas belajar siswa yang berhubungan dengan masalah tersebut. (Ibrahim \& Nur, 2000). Kegiatan membimbing penyelidikan merupakan langkah yang ditempuh guru dalam mendorong siswa untuk mengumpulkan informasi yang sesuai guna mendapatkan pemecahan masalah (Trianto, 2014). Sementara itu, kegiatan mengembangkan dan menyajikan hasil karya adalah kegiatan siswa dalam merencanakan dan menyiapkan hasil kaarya yang sesuai melalui kegiatan kolaborasi dengan semua anggota kelompok (Hartono, 2014). Sedangkan kegiatan menganalisis dan mengevaluasi proses pemecahan masalah adalah kegiatan siswa dalam melakukan refleksi atau evaluasi terhadap proses-proses penyelidikan yang mereka gunakan (Ibrahim \& Nur, 2000).

Karaktersitik pembelajaran berbasis masalah sangat memungkinkan untuk diterapkan guna membantu siswa dalam mengembangkan kemampuan berpikir tingkat tinggi (hight order thinking skills) diantaranya adalah analisis, evalusi, dan mencipta. Sebagaimana diungkapkan oleh Dewey (dikutip dalam Hartono, 2014) bahwa permasalahan yang diangkat dalam pembelajaran berbasis masalah adalah permasalahan aktual yang secara umum belum ada gambaran pemecahan masalahnya, sehingga hal ini dapat mendorong siswa untuk melakukan analisis dan berpikir secara rasional untuk menemukan jawabannya. Beberapa penelitian telah membuktikan bahwa penerapan model pembelajaran berbasis masalah berpengaruh terhadap kemampuan analisis siswa. Penelitian yang dilakukan oleh Saiful (2010) melalui penerapan pembelajaran berbasis masalah dalam penyampaian mata pelajaran matematika terbukti secara signifkan berpengaruh terhadap kemamouan analisis siswa. Penelitian yang dilakukan oleh Anggraeni \& Saliman (2012) melalui penelitian tindakan kelas dengan menerapkan model pembelajaran berbasis pada pembelajaran ilmu pegetahuan sosial menunjukkan bahwa terdapat peningkatan kemampuan berpikir tingkat tinggi siswa secara signifikan pada setiap siklus pembelajaran. Penelitian yang dilakukan oleh Fitria \& Wirahayu (2014) melalui penelitian tindakan kelas melalui implementasi model pembelajaran berbasis masalah pada penyampaian materi geografis menunjukkan hasil bahwa terdapat peningkatan kemampuan analisis siswa secara signifikan pada sertiap siklusnya. Penelitian yag dilakukan oleh Sunaryo (2014) yang menerapkan model pembelajaran berbasis masalah dalam penyampaian materi matematika menunjukkan pengaruh yang signfikan terhadap kemapuan berpikir tingkat tinggi siswa. Penelitian yang dilakukan Wahidin (2014) melalui penerapan pembelajaran berbasis masalah dalam pembelajaran matematika menunjukkan pengaruh yang signifikan terhadap kemampuan analisis dan evaluatif siswa. Penelitian yang dilakukan oleh Yulia (2015) melalui penerapan pembelajaran berbasis masalah terbukti berpengaruh secara signifikan terhadap kemampuan berpikir tingkat tinggi dan kepercayaan diri siswa.

Berdasarkan pada penjelasan di atas, sasaran penelitian ini adalah menerapkan model pembelajaran berbasis masalah dalam upaya untuk meningkatkan kemampuan analisis siswa kelas $\mathrm{X}$ Teknik Pemesinan pada mata pelajaran Keistrikan Mesin dan Konversi Energi.

\section{Metode}

Jenis Penelitian ini adalah penelitian tindakan kelas (classroom action research) atau disingkat PTK. Penelitian Tindakan Kelas Meliputi empat tahapan yaitu perencanaan tindakan, pelaksanaan tindakan, pengamatan tindakan, danrefleksi. Adapun tahap-tahap penelitian yang dilakukan dapat dilihat pada Gambar 1 berikut. 

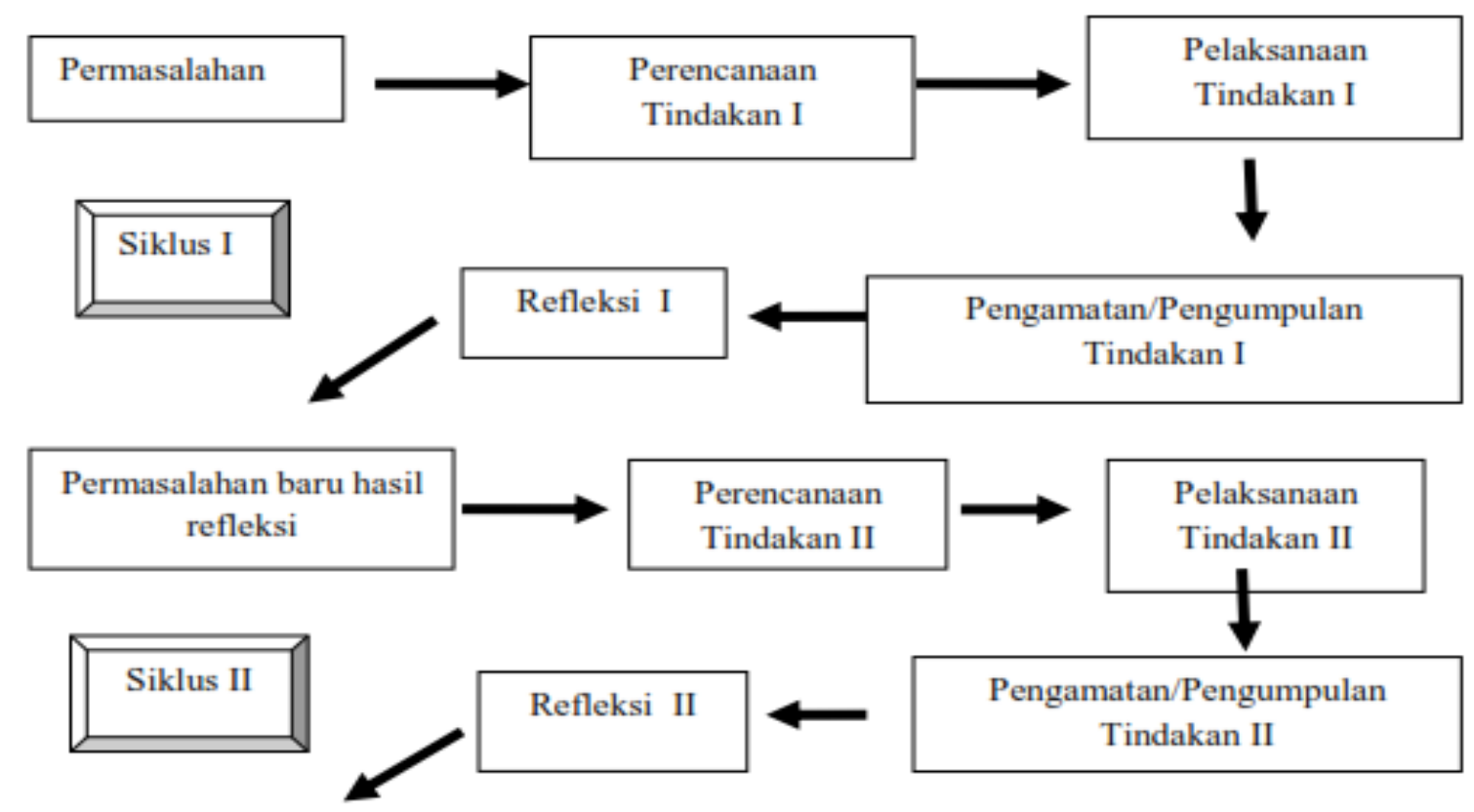

Dilanjutkan ke siklus berikutnya, jika masalah belum selesai

Gambar 1. Diagram Siklus Penelitian Tindakan Kelas (sumber: Arikunto, 2010)

Data yang diperlukan dalam penelitian ini adalah hasil tes kemampuan analisis setelah tindakan. Sumber data pada penelitian ini siswa kelas X Teknik Pemesinan SMK Negeri 3 Mataram tahun ajaran 2017/2018 yang berjumlah 32 siswa. Pelaksanaan penelitian dimulai pada bulan Januari 2018 sampai dengan Maret 2018. Instrumen dalam penelitian ini adalah instrumen tes kemampuan analisis dalam bentuk tes uraian. Instrumen tes kemampuan analisis bertujuan untuk mengukur peningkatan kemampuan analisis siswa, diukur melalui indikator kemampuan analisis Anderson \& Krathwohl (2010) yang meliputi: (1) differentiating, (2) organizing, dan (3) attributingsetelah dilakukan penerapan model pembelajaran pembelajaran berbasis masalah. Data kemampuan berpikir kritisanalisis diperoleh dengan memberikan tes sebagai alat evaluasi kepada siswaTes dalam penelitian inimeliputi tes pra tindakan, tes akhir siklus I, dan tes akhir siklus II.

Peningkatan kemampuan analisis siswa diperoleh dengan menghitung .besarnya skor gain kemampuan analisis yang dinormalisasi (N-gain) dari setiap indikator kemampuan analisis dari siklus pra tindakan, siklus I, dan siklus II.Besarnya N-gain dihitung dengan rumus (Cheng, 2004):

$$
N-\text { gain }=\frac{S_{\text {post }}-S_{\text {pre }}}{S_{\text {maks }}-S_{\text {pre }}} \times 100 \%
$$

Nilai N-gain dikelompokkan dalam kategori tinggi, sedang, dan rendah yang dicantumkan dalam Tabel 1.

Tabel 1. Kriteria Skor N-gain

\begin{tabular}{ll}
\hline Nilai $\mathbf{N}$-gain & Kategori \\
\hline $0.7<\mathbf{N}-$ gain & Tinggi \\
$0.3 \leq \mathbf{N}-$ gain $\leq 0.7$ & Sedang \\
$\mathbf{N}$ - gain $<0.3$ & Rendah \\
\hline
\end{tabular}

(Chenk, 2004)

Untuk menguji tingkat signifikasi perbedaan kemampuan analisis setiap siklus dilakukan uji perbedaan dua rata-rata melalui uji-t dengan bantuan SPSS 20 for Windows dengan terlebih dahulu dilakukan uji normalitas dan uji homogenitas data.

\section{Hasil dan Pembahasan}

Kemampuan analisis siswa dalam penelitian ini terdiri dari kemampuan analisis pra tindakan, kemampuan analisis siklus I, dan kemampuan analisis siklus II. Kemampuan analisispra tindakan dilaksanakan sebelum siswa diberikan tindakan dengan tujuan untuk mengetahui kemampuan awal 
siswa sebelum diberikan tindakan. Berdasarkan data penelitian kemampuan analisis siswa kelas X Teknik Pemesinan SMK Negeri 3 Mataram,pada siklus pra tindakan terdapat $0 \%$ siswa yang memperoleh nilai kemampuan analisis sesuai nilai ketuntasan belajar baik ada indikator differentiating, organizing, maupun attributing. Sedangkan pada siklus I, terdapat $40 \%$ siswa yang mencapai nilai ketuntasan belajar kemampuan analisis pada indikator differentiating, $40 \%$ pada indikator organizing, dan $50 \%$ pada indikator attributing. Sementara itu, pada siklus II terdapat $80 \%$ siswa yang mencapai nilai ketuntasan belajar kemampuan analisis pada indikator differentiating, $80 \%$ pada indikator organizing, dan $82.5 \%$ pada indikator attributing. Deskripsi pencapaian nilai kemampuan analisis dan $\mathrm{N}$-gain pada setiap indikator dan pada setiap siklus dicantumkan dalam Tabel 2.

\section{Tabel 2. Deskripsi Kemampuan Analisis Siswa}

\begin{tabular}{llllllll}
\hline \multirow{2}{*}{ No } & \multirow{2}{*}{$\begin{array}{l}\text { Indikator Kemampuan } \\
\text { Analisis }\end{array}$} & \multicolumn{2}{l}{ Kemampuan Analisis Siswa $(\mathrm{KB}=70)$} \\
\cline { 3 - 7 } & & \multicolumn{2}{l}{ Pra Siklus (N=40) } & \multicolumn{2}{l}{ Siklus I (N=40) } & \multicolumn{2}{c}{ Siklus II (N=40) } \\
\cline { 2 - 7 } & & $\bar{X}$ & SD & $\bar{X}$ & SD & $\bar{X}$ & SD \\
\hline 1 & Differentiating & 16,63 & 7,54 & 54 & 6,09 & 69,03 & 12,39 \\
2 & Organizing & 7,50 & 5,55 & 64,13 & 11,63 & 76,88 & 8,53 \\
3 & Attributing & 4,75 & 2,99 & 61,13 & 12,39 & 75,88 & 9,53 \\
\hline
\end{tabular}

Keterangan

KB : Nilai ketuntasa belajar

$\mathrm{N}$ : Jumlah siswa

$\bar{X} \quad: \quad$ Nilai rata-rata kemampuan analisis

SD : Standar Deviasi

Uji beda rata-rata terhadap data yang dicantumkan pada Tabel 2 dilakukan terhadap setiap sumber data. Uji beda rata-rata kemampuan analisis siswa pada setiap indikator antara pra siklus dengan siklus I diperoleh nilai, diperoleh nilai $t_{\text {hitung }}$ $=30,339$ dan $t_{\text {tabel }}=1,991$ pada taraf kepercayaan 0,05 untuk indikator differentiating. Dengan demikian dapat disimpulkan bahwa terdapat perbedaan yang signifikan terhadap nilai rata-rata kemampuan analisis indikator differentiatingantara pra siklus dengan siklus I dimana nilai rata-rata pada siklus I lebih tinggi secara signifikan dibanding nilai rata-rata pada pra siklus. Sementara itu untuk indikator organizing diperoleh nilai $t_{\text {hitung }}=26,323$ dan $t_{\text {tabel }}=1,991$ pada taraf kepercayaan 0,05 . Dengan demikian dapat disimpulkan bahwa terdapat perbedaan yang signifikan terhadap nilai rata-rata kemampuan analisis indikator organizing antara pra siklus dengan siklus I dimana nilai rata-rata pada siklus I lebih tinggi secara signifikan dibanding nilai rata-rata pada pra siklus. Sedangkan untuk indikator attributingdiperoleh nilai $t_{\text {hitung }}=26,323$ dan $t_{\text {tabel }}$ $=1,991$ pada taraf kepercayaan 0,05. Dengan demikian dapat disimpulkan bahwa terdapat perbedaan yang signifikan terhadap nilai rata-rata kemampuan analisis indikator attributing antara pra siklus dengan siklus I dimana nilai rata-rata pada siklus I lebih tinggi secara signifikan dibanding nilai rata-rata pada pra siklus.

Uji beda rata-rata kemampuan analisis siswa pada setiap indikator antara siklus I dengan siklus II diperoleh nilai, diperoleh nilai $t_{\text {hitung }}=7,699$ dan $t_{\text {tabel }}=1,991$ pada taraf kepercayaan 0,05 untuk indikator differentiating. Dengan demikian dapat disimpulkan bahwa terdapat perbedaan yang signifikan terhadap nilai rata-rata kemampuan analisis indikator differentiating antara siklus I dengan siklus II dimana nilai rata-rata pada siklus II lebih tinggi secara signifikan dibanding nilai ratarata pada pra siklus. Sementara itu untuk indikator organizingdiperoleh nilai $t_{\text {hitung }}=6,908$ dan $t_{\text {tabel }}=$ 1,991 pada taraf kepercayaan 0,05. Dengan demikian dapat disimpulkan bahwa terdapat perbedaan yang signifikan terhadap nilai rata-rata kemampuan analisis indikator organizing antara siklus I dengan siklus II dimana nilai rata-rata pada siklus II lebih tinggi secara signifikan dibanding nilai rata-rata pada siklus I. Sedangkan untuk indikator attributing diperoleh nilai $t_{\text {hitung }}=2,772$ dan $t_{\text {tabel }}=1,991$ pada taraf kepercayaan 0,05 . Dengan demikian dapat disimpulkan bahwa terdapat perbedaan yang signifikan terhadap nilai rata-rata kemampuan analisis indikator attributing antara sklus I dengan siklus II dimana nilai rata-rata pada 
siklus II lebih tinggi secara signifikan dibanding nilai rata-rata pada siklus I.
Perbandingan nilai rata-rata kemampuan analisis setiap indikator pada setiap siklus ditampilkan dalam Gambar 2.

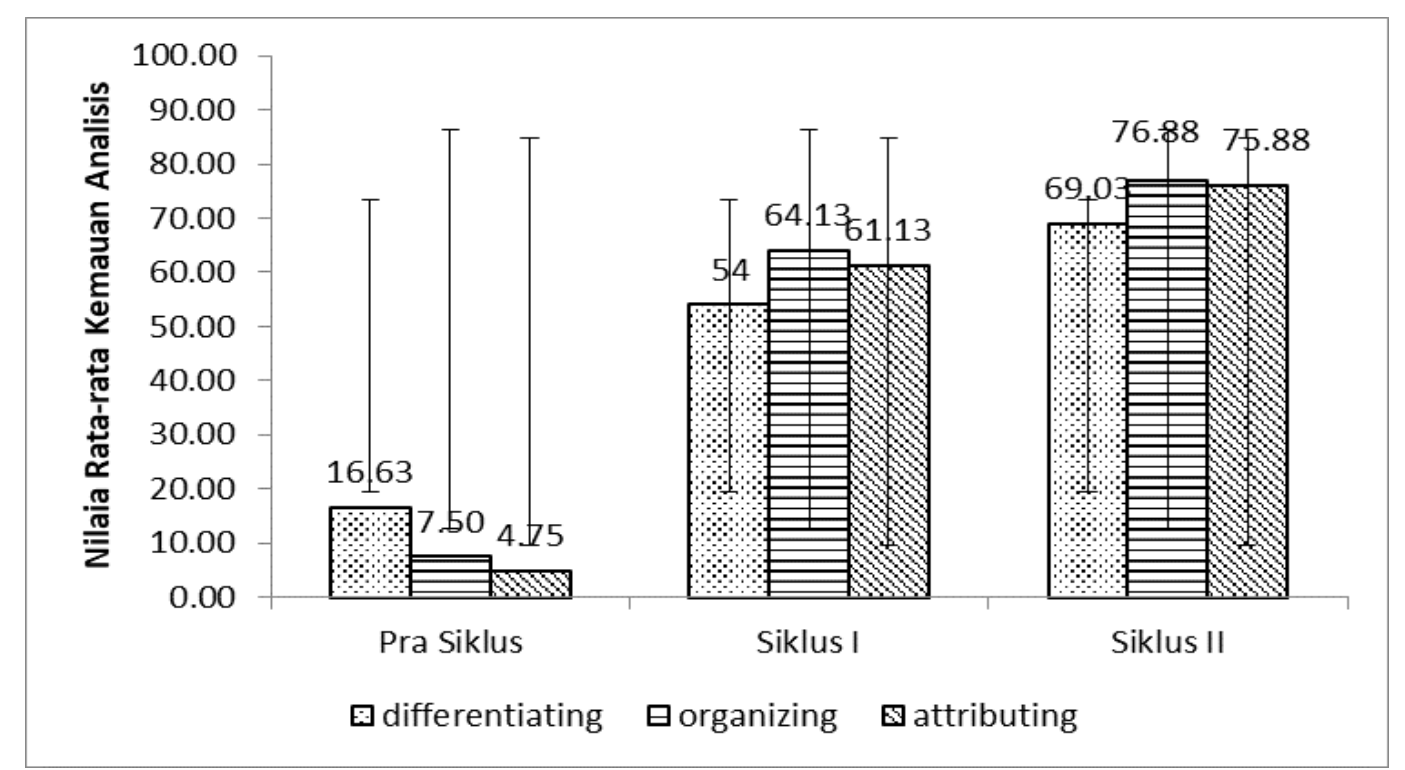

Gambar 2. Perbandingan Pencapaian Nilai Rata-rata Kemampuan Analisis Setiap Indikator pada Setiap Siklus

Deskripsi $\mathrm{N}$-gain pada setiap indikator dan pada siklus I dan siklus II dicantumkan dalam Tabel 3.

Tabel 2. Deskripsi N-gain Siklus I dan Siklus II

\begin{tabular}{llllll}
\hline \multirow{2}{*}{ No } & \multirow{2}{*}{ Indikator Kemampuan Analisis } & Siklus I & \multicolumn{3}{c}{ Siklus II } \\
\cline { 3 - 5 } & N-gain & Kriteria & N-gain & Kriteria \\
\hline 1 & Differentiating & 0,45 & Sedang & 0,63 & Sedang \\
2 & Organizing & 0,61 & Sedang & 0,75 & Tinggi \\
3 & Attributing & 0,59 & Sedang & 0,75 & Tinggi \\
\hline
\end{tabular}

Sesuai dengan perolehan N-gain, terdapat peningkatan kemampuan analisis pada setiap indikator dari siklus I ke siklus II setiap siklus. Uji beda rata-rata terhadap skor $\mathrm{N}$-gain dilakukan untuk mengetahui signifikasi perbedaan peningkatan kemampuan analisis pada setiap indiaktor dari siklus I ke siklus II. Berdasarkan hasil uji beda rata-rata, diperoleh nilai $t_{\text {hitung }}=4,983$ dan $t_{\text {tabel }}=1,991$ pada taraf kepercayaan 0,05 untuk indikator differentiating. Dengan demikian dapat disimpulkan bahwa terdapat peningkatan yang signifikan pada kemampuan analisis indikator differentiatingantara siklus I dengan siklus II. Sementara itu untuk indikator organizingdiperoleh nilai $t_{\text {hitung }}=9,031$ dan $t_{\text {tabel }}=1,991$ pada taraf kepercayaan 0,05. Dengan demikian dapat disimpulkan bahwa terdapat peningkatan yang signifikan terhadap nilai rata-rata kemampuan analisis indikator organizingantara siklus I dengan siklus II. Sedangkan untuk indikator attributingdiperoleh nilai $t_{\text {hitung }}=6,227$ dan $t_{\text {tabel }}=$ 1,991 pada taraf kepercayaan 0,05. Dengan demikian dapat disimpulkan bahwa terdapat peningkatan yang signifikan terhadap nilai rata-rata kemampuan analisis indikator attributing antara sklus I dengan siklus II.

Perbandingan $\mathrm{N}$-gain kemampuan analisis setiap indikator pada Siklus I dan Siklus II ditampilkan dalam Gambar 3. 


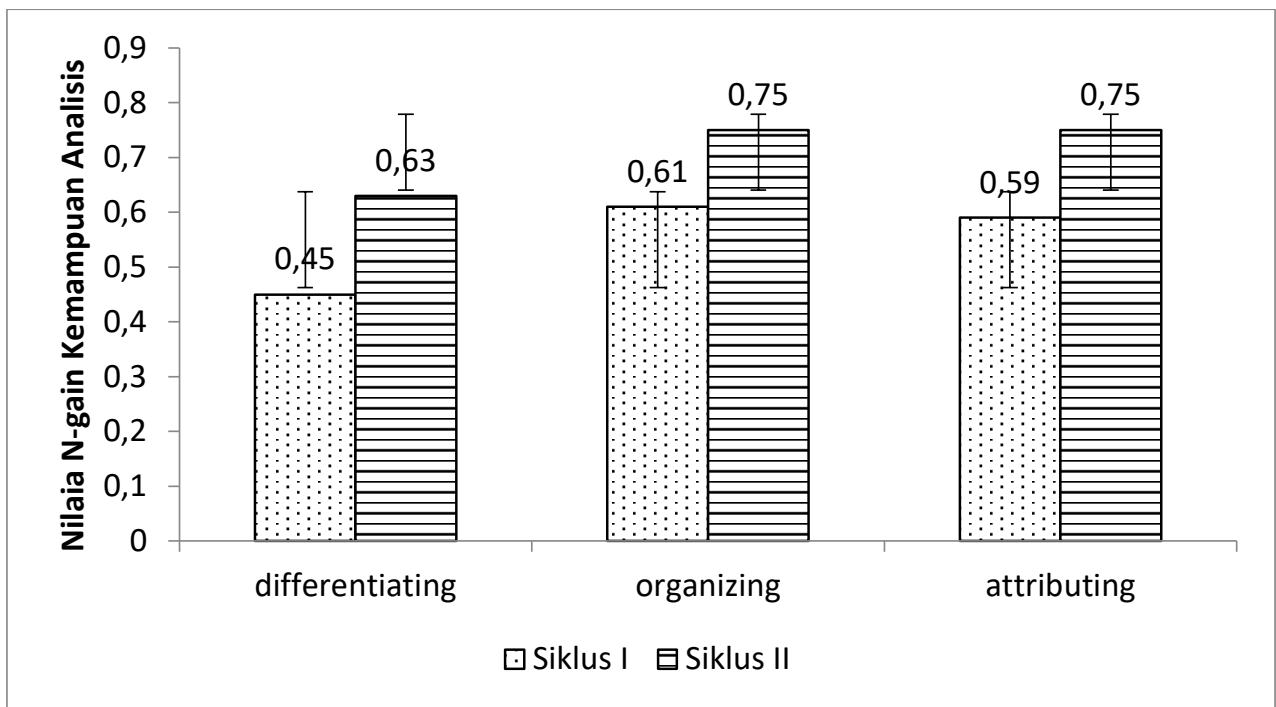

Gambar 2. Perbandingan N-gain Kemampuan Analisis Setiap Indikator pada Siklus I dan Siklus II

Proses differentiating dalam penelitian ini adalah kemampuan siswa dalam membedakan bagian dari pengetahuan yang jika dipadukan dapat menyusun informasi yang berkaitan dengan fenomena kelistrikan mesin. Aktivitas siswa yang dimulai dari analisis data aktual yang disajikan dalam tahap penyajian permasalahan, dilanjutkan dengan diskusi, penyusunan pemecahan masalah, menyajikan masalah, dan menarik referensi, membantu siswa untuk menggabungkan beberapa pemahaman dalam rangka menginterpretasi menjadi informasi yang lebih bermakna. Sementara itu, proses organizing adalah mengukur kemampuan siswa dalam mengidentifikasi sederetan informasi dan fakta yang disajikan berkaitan dengan permasalahan kelistrikan mesin. Kegiatan siswa dalam mengkonstruksi pemahamannya yang dimulai dari analisis data aktual yang disajikan dalam tahap penyajian permasalahan, dilanjutkan dengan diskusi, penyusunan pemecahan masalah, menyajikan masalah, dan menarik referensi, membantu siswa dalam mengelola sekumpulan informasi dan fakta tersebut, untuk digabung menjadi sebuah keluaran informasi baru sebagai salah satu bentuk solusi dari permasalahan yang diberikan. Sedangkan proses attributing adalah kemampuan siswa untuk menemukan kata kunci dari sekumpulan informasi kelistrikan mesinyang diberikan, dengan kata kunci tersebut siswa mampu mengembangkan untuk dijadikan sebagai titik permasalahan guna menemukan solusi permasalahan.

Peningkatan kemamuan analisis siswa salah satunya disebabkan adanya pendekatan penyajian konsep dari materi yang dipelajari. Konsep-konsep yang dikonstruksi sendiri oleh siswa mempermudah siswa dalam memahami materi kelistrikan mesin. Meningkatnya kemampuan analisis siswa, karena pada model pembelajaran berbasis masalah, siswa lebih memahami konsep yang diajarkan sebab mereka sendiri yang menemukan masalah tersebut serta dibiarkan mencarisolusi terhadap permasalahanyaitu berkaitan dengan lingkungan sekitar. Dari pemahaman siswa itu, kemampuan siswa dalam merumuskan suatu permasalahan juga menjadi lebih baik. Guru lebih melibatkan siswa dalam proses pembelajaran, sehingga siswa menjadi aktif dalam proses diskusi berlangsung.

Pembelajaran berbasis masalah membantu siswa dalam mengembangkan kemampuan mengambil keputusan. Apabila kemampuan dalam mengambil keputusan meningkat, maka pengambilan keputusan oleh siswa dalam mencari alternatif permasalahan yang diberikan oleh guru akan menjadi lebih baik. Selain itu dalam pembelajaran berbasis masalah, membuat siswa lebih aktif dan mempunyai tanggung jawab tentang pembagian tugas dalam anggota kelompoknya, sehingga tugas yang diberikan oleh guru dapat terselesaikan dengan baik.

Pemberian motivasi dalam belajar membuat siswa lebih antusias dalam belajar. Karena motivasi tersebut, antusiasme siswa menjadi lebih besar, siswa mendapatkan pengalaman pribadi dari lingkungan di kelas maupun lingkungan sekitar. Apabila motivasi dan antusiasme siswa meningkat, maka dorongan untuk melakukan investigasi dalam 
berdiskusi menjadi lebih baik. Motivasi tersebut juga membuat siswa mau untuk belajar terlebih dahulu sebelum pelajaran di dalam kelas. Hal ini mendorong siswa untuk meningkatkan kemampuan berpikir kritisnya. Selain itu, siswa menjadi lebih inovatif dalam menyajikan hasil karyanya.

\section{Kesimpulan}

Hasil Penelitian menunjukan bahwa penerapan pembelajaran masalah dapat meningkatkan kemampuan analisis siswa kelas $\mathrm{X}$ Teknik Pemesinan SMK Negeri 3 Mataram pada mata pelajaran Kelistrikan Mesin dan Konversi Energi. Peningkatan ditunjukkan dengan meningkatnya prosentaase siswa ang mencapai nilai ketuntasan belajar. Peningkatan nilai ketuntasan belajar pada akhir siklus pembelajaran juga ditunjukkan pada peningkatan kemampuan analisis siswa pada setiap indikator kemampuan analisis, meliputi: differentiating, organizing, dan attributing.

\section{Saran}

Pada saat penerapan model pembelajaran berbasis masalah hendaknya guru perlu memperhatikan pengelolaan kelas yang lebih baik terutama dalam mengatasi siswa yang sering membuat ramai dan gaduh, sehingga pelaksanaan kegiatan pembelajaran dapat berjalan dengan baik dan lancar. Guru maupun praktisi pendidik dapat menerapkan model pembelajaran berbasis masalah sebagai salah satu alternatif pembelajaran dalam meningkatkan kemampuan analisis siswa.

\section{Daftar Pustaka}

Anderson, L.W dan Krathwohl, D.R. 2010. Kerangka Landasan untuk Pembelajaran, Pengajaran dan Asesmen (Revisi Taksonomi Pendidikan Bloom). Yogyakarta: Pustaka Pelajar

Anggraeni, L. \& Saliman. 2012. Penerapan Model Pembelajaran Berbasis Masalah untuk Meningkatkan Kemampuan Analisissiswa Mata Pelajaran IPS Di SMP N 2 Depok Yogyakarta, e-Jornal Social Studies, Vol
1,Edisi Tahun 2012, 12-20, diakses melalui

http://journal.student.uny.ac.id/jurnal/artik el/948/39/183, tanggal 30 Maret 2016

Arikunto, S. 2010. Prosedur Penelitian Suatu Pendekatan Praktik. Jakarta: PT Bumi Aksara.

Chenk, K. 2004. Using Online Homeworks System Enhances Student Learning of Physics Concept in an Introductory Physics Course. American Journal of Physics. 72 (11) 1447-1453.

DitPSMK (2017). Analisis Standar Kompetensi Lulusan, Kompetensi Inti, dan Kompetensi Dasar. Jakarta: Kementrian Pendidikan dan Kebudayaan.

Fitria, N.N., \& Wirahayu, Y.A. 2014. Model Pembelajaran Berbasis Masalah untuk Meningkatkan Kemampuan Analisis Geografi Siswa SMA, online, diakses melalui http://ejournal.unp.ac.id, tanggal 30 Maret 2016.

Hartono, R. 2014. Ragam Model Mengajar yang Mudah diterima Murid. Yogyakarta: DIVA Press.

Ibrahim, M., \& Nur, M. 2000. Pengajaran Berbasis Masalah. Surabaya: University Press.

Kemendiknas. 2013. Peraturan Menteri Pendidikan Pendidikan dan Kebudayaan Republik Indonesia Nomor 70 Tahun 2013 Tentang Kerangka Dasar dan Struktur Kurikulum Sekolah Menengah Kejuruan/Madrasah Aliyah Kejuruan. Jakarta: Kementrian Pendidikan Nasional

Marzano, R.J, \& Kendall, J.S. 2008. Designing \& Assessing Educational Objective. California: Corwin Press.

Muhaimin, A. 2015. Pengembangan Media Riil Kelistrikan Mesin dan Pengaruhnya Terhadap Peningkatan Pemahaman Konsep Siswa SMK. Proceeding Seminar Nasional, SMA Negeri 7 Mataram, 7 Desember 2015.

Saiful, A.M. 2010. Efektivitas Pembelajaran Berbasis Masalah Dalam Meningkatkan Kemampuan Analisis Siswa di Kelas VII-B Madrasah Tsanawiyah Negeri Purwoasri Kediri. Tesis, UIN Sunan Ampel Surabaya, diakses melalui http://repository.uinsunanampel.ac.id/, tanggal 28 Maret 2016 
Sunaryo, Y. (2014). Model Pembelajaran Berbasis Masalah untuk Meningkatkan Kemampuan Analisisdan Kreatif Matematik Siswa SMA di Kota Tasikmalaya, on line, diakses melalui http://pasca.ut.ac.id/journal/index.php/JP K/article/view/58, tangal 26 Maret 2016

Trianto. (2014). Model Pembelajaran Terpadu. Jakarta: Bumi Aksara

Trilling, B., \& Fadel, C. . (2009). 21 st Century Skills Learning for Life in Our Times. San Fransisco: Wiley

Wahidin, A.N. (2014). Pembelajaran Berbasis Masalah (PBM) untuk Meningkatkan Kemampuan Analisis dan Evaluasi Matematik Siswa SMP Tesis, Universitas Pendidikan Indonesia, tidak dipublikasikan, diakses melalui. http://repository.upi.edu/ tanggal 26 Maret 2016

Yulia, N.D. (2015). Penerapan Pembelajaran Berbasis Masalah untuk Meningkatkan Kemampuan Berpikir Kreatif Dan SelfConfidence Siswa SMP, online, diakses melalui http://repository.unpas.ac.id/1038/ tanggal 28 Maret 2016. 